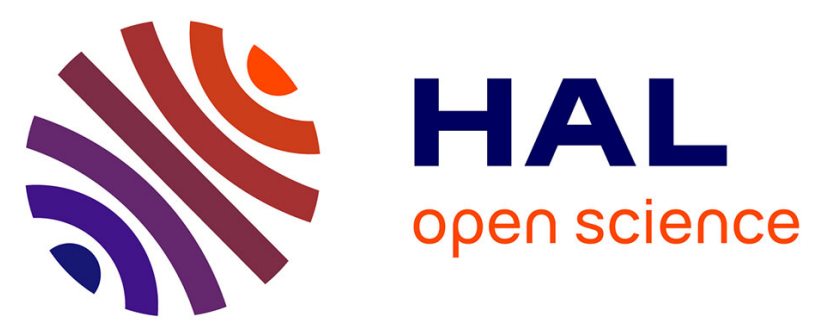

\title{
Approaching industrially relevant current densities for hydrogen oxidation with a bioinspired molecular catalytic material
}

Jérémy Schild, Bertrand Reuillard, Adina Morozan, Pascale Chenevier, Edmond Gravel, Eric Doris, Vincent Artero

\section{To cite this version:}

Jérémy Schild, Bertrand Reuillard, Adina Morozan, Pascale Chenevier, Edmond Gravel, et al.. Approaching industrially relevant current densities for hydrogen oxidation with a bioinspired molecular catalytic material. Journal of the American Chemical Society, 2021, 143 (43), pp.18150-18158. 10.1021/jacs.1c07093 . hal-03406054

\section{HAL Id: hal-03406054 https://hal.science/hal-03406054}

Submitted on 27 Oct 2021

HAL is a multi-disciplinary open access archive for the deposit and dissemination of scientific research documents, whether they are published or not. The documents may come from teaching and research institutions in France or abroad, or from public or private research centers.
L'archive ouverte pluridisciplinaire HAL, est destinée au dépôt et à la diffusion de documents scientifiques de niveau recherche, publiés ou non, émanant des établissements d'enseignement et de recherche français ou étrangers, des laboratoires publics ou privés. 


\title{
Approaching industrially relevant current densities for Hydrogen Ox- idation with a bio-inspired molecular catalytic material.
}

\author{
Jérémy Schild, ${ }^{\dagger \neq}$ Bertrand Reuillard, ${ }^{\dagger *}$ Adina Morozan, ${ }^{\dagger}$ Pascale Chenevier, ${ }^{\S}$ Edmond Gravel, ${ }^{\ddagger}$ \\ Eric Doris ${ }^{\ddagger}$ and Vincent Artero ${ }^{\dagger *}$
}

† Univ. Grenoble Alpes, CNRS, CEA, IRIG, Laboratoire de Chimie et Biologie des Métaux, 17 rue des Martyrs, F38054 Grenoble, Cedex, France; vincent.artero@cea.fr

‡ Université Paris-Saclay, CEA, INRAE, Département Médicaments et Technologies pour la Santé (DMTS), SCBM, 91191 Gif-sur-Yvette, France.

§ Univ. Grenoble Alpes, CNRS, CEA, IRIG, SyMMES, 17 rue des Martyrs, F-38054 Grenoble, Cedex, France.

\begin{abstract}
Integration of efficient platinum group metal (PGM)-free catalysts to fuel cells and electrolysers is a prerequisite to their large-scale deployment. Here, we describe the development of a molecular based anode for hydrogen oxidation reaction (HOR) through non-covalent integration of a DuBois type Ni bio-inspired molecular catalyst at the surface of a carbon nanotubes modified gas diffusion layer. This mild immobilization strategy enabled to gain high control over the loading in catalytic sites. Additionally, through the adjustment of the hydration level of the active layer, new record current densities of $214 \pm 20 \mathrm{~mA} \mathrm{~cm}{ }^{-2}$ could be reached at $0.4 \mathrm{~V}$ vs RHE with a PGM-free anode, at $25^{\circ} \mathrm{C}$. Near-industrially relevant current densities were obtained at $55^{\circ} \mathrm{C}$ with $150 \pm 20$ and $395 \pm 30 \mathrm{~mA} \mathrm{~cm}^{-2}$ at 0.1 and $0.4 \mathrm{~V}$ overpotential, respectively. These results further demonstrate the relevance of such molecular approaches for the development of electrocatalytic platforms for energy conversion.
\end{abstract}

\section{Introduction}

The development of a hydrogen economy stands among the most promising strategies towards achieving clean energy storage and on-demand fuel supply. ${ }^{1,2}$ However, for this alternative to become sustainable, $\mathrm{H}_{2}$-producing electrolyzers and $\mathrm{H}_{2}$-consuming fuel cells $(\mathrm{FC})$ need to reach technological maturity while relying on broadly available raw materials. ${ }^{3,4}$ On the fuel cell front, Pt-group metals (PGMs) catalysts currently represent a significant part of the cost of proton-exchange membrane fuel cells (PEMFCs). ${ }^{5}$ While a substantial body of work have now been reported within the past ten years for the development of PGM-free cathode for ORR, ${ }^{6-9}$ especially with the recent and promising development of metal-N-C based materials, ${ }^{10-12}$ alternatives to PGMs on the anode side are more scarce. ${ }^{13}$ Although recent studies have described metal-containing carbides ${ }^{14-17}$ and Ni-based materials ${ }^{18-20}$ for HOR catalysis, these materials only display moderate activities and stabilities under operation.

Hydrogenases enzymes ( $\mathrm{H}_{2}$ ases) are Nature's catalysts performing hydrogen evolution reaction (HER) and HOR in a reversible manner, with very high turnover frequencies (TOFs), up to $10^{4} \mathrm{~s}^{-1}$, using only earth abundant $\mathrm{Ni}$ and/or Fe metals in their catalytic centres. ${ }^{21-23}$ Due to these impressive catalytic properties and in light of the recent progress in the field of bioelectrochemistry, ${ }^{24-26}$ these $\mathrm{H}_{2}$ ases have been extensively studied at electrode surfaces. ${ }^{27-29}$ As a result, proof-of-concept, $\mathrm{H}_{2}-\mathrm{O}_{2}$ biofuel cells relying on $\mathrm{H}_{2}$ ase based anodes for HOR were devel- oped, ${ }^{30-32}$ with maximum power densities now reaching several $\mathrm{mW} \mathrm{cm}^{-2} .33,34$ Despite these recent advances, the use of $\mathrm{H}_{2}$ ases for this technology remains challenging due to their large molecular footprint and limited stability. Several strategies have been investigated to overcome these limitations. $\mathrm{H}_{2}$ ase orientation at the electrode surface has been proposed to optimize electron transfers between the redox protein and the material. ${ }^{35,36}$ Recently, viologen-based hydrogels have demonstrated impressive properties not only to efficiently wire the enzyme but also to shield even the most fragile types of $\mathrm{H}_{2}$ ases against molecular $\mathrm{O}_{2}$, for extended period of time, upon integration in the redox active matrix. ${ }^{37-40}$ However, site density optimization and non-aqueous instability remain problematic for these bioelectrodes to be integrated to market ready PEMFCs.
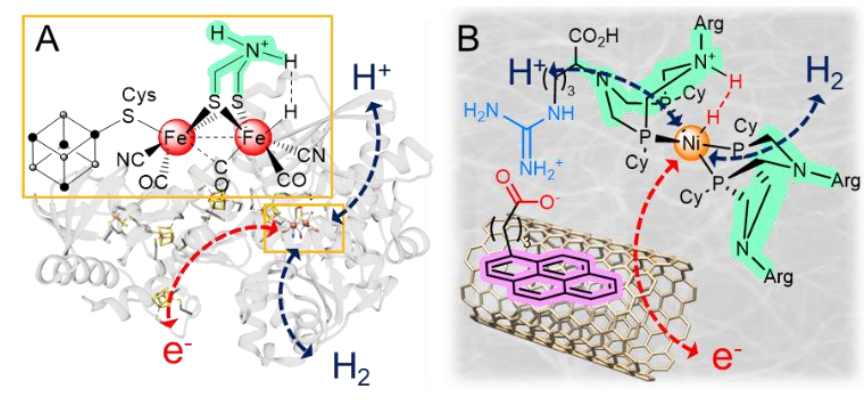

Figure 1: Schemes of A) a $[\mathrm{FeFe}]$ hydrogenase $\left(\left[\mathrm{H}_{\mathrm{hyd}} \mathrm{H}^{+}\right]^{+}\right.$ state) and $\mathrm{B}$ ) the Ni-based bio-inspired nanomaterial for reversible $\mathrm{HER} / \mathrm{HOR}$, showing the natural and synthetic 
components responsible for electron shuttling as well as $\mathrm{H}^{+}$ and $\mathrm{H}_{2}$ channels.

The relatively recent application of bio-inspiration to the development of electrocatalysts for energy conversion has led to the generation of novel and promising new catalytic materials, molecular catalysts and devices. ${ }^{41,42}$ One prime example of this approach has been the development of the first bi-directional catalyst for HER and HOR by the group of DuBois. ${ }^{43}$ This $\left[\mathrm{Ni}^{\mathrm{II}}\left(\mathrm{P}_{2}{ }^{\mathrm{R}} \mathrm{N}_{2}{ }^{\mathrm{R}}\right)_{2}\right]$ type complex was designed based on the natural [NiFe]- and [FeFe]- $\mathrm{H}_{2}$ ase blueprints. It relies on both a mononuclear $\mathrm{Ni}$ redox center and a 1,5-diaza-3,7-diphosphacyclooctane $\left(\mathrm{P}_{2}{ }^{\mathrm{R}} \mathrm{N}_{2}{ }^{\mathrm{R}}\right)$ macrocyclic ligand mimicking the 2azapropanedithiolate bridge present in [FeFe]- $\mathrm{H}_{2}$ ases, both acting as proton shuttle and forming with the distal iron center a frustrated Lewis pair able to activate and heterolytically cleave $\mathrm{H}_{2}$ (Figure 1 )..$^{4,45}$ The possibility to modify the nature of the side chain carried by the cyclic amine has led to the development of new derivatives with extended outer coordination sphere, with a substantial body of work by Shaw and co-workers focusing on the introduction of amino acid residues, mimicking protein environments. ${ }^{4-48}$ This strategy led to the discovery of the $\left[\mathrm{Ni}^{\mathrm{II}}\left(\mathrm{P}_{2}{ }^{\mathrm{Cy}} \mathrm{N}_{2}{ }^{\mathrm{Arg}}\right)_{2}\right]^{7^{+}}$(NiArg) derivative (Figure ${ }_{1} \mathrm{~B}$ ), the first to demonstrate a fully reversible activity for HER and HOR in neutral to acidic aqueous conditions and owing the strongest reported bias towards HOR. ${ }^{49-51}$

As the tertiary amine substituents have allowed the modification of the outer coordination sphere, they can also enable the incorporation of anchoring groups for surface heterogenization, a prerequisite to shift molecular catalysis towards applications..$^{52-54}$ As such, over the past decade, several covalent and non-covalent immobilization strategies have been developed in order to integrate these $\left[\mathrm{Ni}^{\mathrm{II}}\left(\mathrm{P}_{2}{ }^{\mathrm{R}} \mathrm{N}_{2}{ }^{\mathrm{R}}\right)_{2}\right]$ derivatives on a broad range of (photo)electrode materials, towards (photo)electrocatalytic $\mathrm{H}_{2}$ production and/or oxidation. ${ }^{55^{-67}}$ More specifically, regarding molecular $\mathrm{HOR}$, initial studies reported current densities of 1 to $2 \mathrm{~mA} \mathrm{~cm}$ on carbon nanotubes (CNTs) based electrodes while demonstrating a high tolerance to CO poisoning. ${ }^{55,56}$ More recent work using nanostructured materials such as CNTs/microfibers composite or functionalized graphene allowed to reach one order of magnitude higher current densities. ${ }^{62,64,66}$ Integration of this family of catalyst to appropriate electrode material has also led to the elaboration of fully functional, proof-ofconcept, bio-inspired $\mathrm{H}_{2} / \mathrm{O}_{2}$ fuel cells. ${ }^{64,68-70}$ Despite promising results, current densities obtained with these molecular anodes remain far too low when compared with PGM-based anodes to be considered as a valid alternative in $\mathrm{H}_{2} / \mathrm{O}_{2}$ fuel cells. According to the Department of Energy (DOE), in order to reach technological relevance, current densities in the range of the hundreds of $\mathrm{mA} \mathrm{cm}$ with minimal energy loss and extended durability should be targeted with these non-PGM anodes. ${ }^{71}$ As for Pt-based electrodes, one of the major challenge consists in optimizing active site loadings while maintaining their availability to the substrate..$^{72-74}$ This implies the preservation of a stable triple electrode/electrolyte/gas interface.
In this work, we report the development of a new molecular anode for HOR based on the integration of the NiArg derivative to multi walled CNTs (MWCNTs) deposited onto a gas diffusion layer (GDL) and non-covalently modified with a pyrene butyric acid derivative $\left(\mathrm{PyCO}_{2} \mathrm{H}\right)$. Assembly of the NiArg derivative to the modified MWCNTs surface occurs through electrostatic interactions between the carboxylate surface functions and the guanidinium groups of the complex, as previously proposed (Figure $1 \mathrm{~B}$ ). ${ }^{64,66}$ This strategy enables to gain high control over the surface concentration of anchoring sites and thus on the catalytic sites density. In addition, the hydration level of the catalytic active layer was controlled through the tuning of the storage conditions and drying time during electrode formulation. This allowed to optimize catalytic site availability and accessibility, to efficiently perform the HOR catalysis throughout the MWCNTs $\mid$ GDL electrode.

\section{Results and discussion}

Preparation of the electrodes. The electrodes were prepared through vacuum filtration of a MWCNTs dispersion (0.05 $\mathrm{mg} \mathrm{mL}^{-1}$ in $\mathrm{EtOH}, 40 \mathrm{~mL}$ ) on a $10 \mathrm{~cm}^{2}$ disk of a GDL coated with a hydrophobic microporous layer. The MWCNTs films were then non-covalently functionalized by soaking the MWCNTs|GDL disks in a DMF solution containing the $\mathrm{PyCO}_{2} \mathrm{H}$ derivative, cautiously preventing the film to dry. This mild surface modification strategy of CNTs sidewall was previously successfully employed to graft molecular catalysts, for a range of catalytic transformations. $^{56,75-78}$ The modified MWCNTs|GDL samples were then successively soaked in DMF to remove excess of unbound $\mathrm{PyCO}_{2} \mathrm{H}$ derivative and deionized water to wash out remaining DMF. The samples were stored in deionized water to prevent the film to dry. Series of MWCNTs|GDL samples were prepared, using different concentrations of $\mathrm{PyCO}_{2} \mathrm{H}$ in order to vary the surface concentration of carboxylic units prior to catalyst integration.
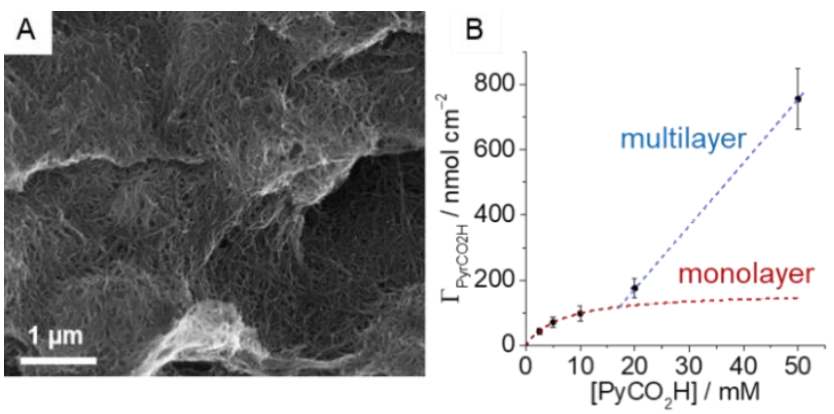

Figure 2: A) SEM picture of the NiArg $\left|\mathrm{PyCO}_{2} \mathrm{H}\right| \mathrm{MWCNTs}$ GDL electrode surface B) Evolution of the surface concentration of $\mathrm{PyCO}_{2} \mathrm{H}$ with the soaking solution concentration. Experimental values were determined by UV-vis (black dots) and the theoretical Langmuir isotherm fit (red dashes) (the blue dashed line is a guide to the eye).

As observed by scanning electron microscopy (SEM), the MWCNTs film deposited onto the GDL forms a dense but porous conductive network, allowing for the integration 
of high amounts of catalytic centers (Figure 2A). A cross sectional image of the MWCNTs|GDL shows that the MWCNTs film thickness is $\approx 5 \mu \mathrm{m}$ (Figure $\mathrm{S}_{1}$ ).

The surface concentrations of $\mathrm{PyCO}_{2} \mathrm{H}\left(\Gamma_{\mathrm{PyCO}_{2} \mathrm{H}}\right)$ on the MWCNTs|GDL were estimated indirectly by measuring the remaining concentrations of $\mathrm{PyCO}_{2} \mathrm{H}$ in the soaking and rinsing DMF solutions, using the strong UV-vis absorption bands, typical of pyrene, at 314, 328 and $344 \mathrm{~nm}$ (see SI). Experimental data show that $\Gamma_{\mathrm{PyCO}_{2} \mathrm{H}}$ increases with the solution concentration, reaching $98 \pm 23 \mathrm{nmol}$ $\mathrm{cm}^{-2}$ at $10 \mathrm{mM}$ of $\mathrm{PyCO}_{2} \mathrm{H}$ in the incubation solution (Figure $2 \mathrm{~B}$ ). $\Gamma_{\mathrm{PyCO}_{2} \mathrm{H}}$ then further increases, reaching $755 \pm$ $94 \mathrm{nmol} \mathrm{cm}{ }^{-2}$ at $50 \mathrm{mM}$. The experimental data points obtained between o and $10 \mathrm{mM}$ could be fitted with a simple Langmuir isotherm as follow:

$$
\Gamma_{\mathrm{PyCO} 2 \mathrm{H}}=\frac{\Gamma_{\mathrm{PyCO} \mathrm{Hmax}_{\max } \mathrm{K}_{\mathrm{PyCO} \mathrm{H}}\left[\mathrm{PyCO}_{2} \mathrm{H}\right]}}{1+K_{\mathrm{PyCO} \mathrm{H}}\left[\mathrm{PyCO}_{2} \mathrm{H}\right]}
$$

where $\Gamma_{\mathrm{PyCO}_{2} \mathrm{Hmax}}$ is the maximum $\mathrm{PyCO}_{2} \mathrm{H}$ surface loading for a monolayer $\left(\mathrm{mol} \mathrm{cm}{ }^{-2}\right), \mathrm{K}_{\mathrm{PyCO}_{2} \mathrm{H}}$ is the adsorption equilibrium constant of $\mathrm{PyCO}_{2} \mathrm{H}\left(\mathrm{M}^{-1}\right)$ and $\left[\mathrm{PyCO}_{2} \mathrm{H}\right]$ is the concentration of $\mathrm{PyCO}_{2} \mathrm{H}$ in solution (M). A best fit was obtained for $\Gamma_{\mathrm{PyCO}_{2} \mathrm{Hmax}}=165 \mathrm{nmol} \mathrm{cm}{ }^{-2}$ and $\mathrm{K}=150$ $\mathrm{M}^{-1}$ in DMF (Figure $2 \mathrm{~B}$ ). This value is in the same range as the ones measured for other pyrene-bearing derivatives grafted on MWCNTs. ${ }^{78,79}$ As $\Gamma_{\mathrm{PyCO}_{2} \mathrm{H}}$ keeps rising above the expected monolayer loading $\left(\Gamma_{\mathrm{PyCO}_{2} \mathrm{Hmax}}\right)$, it is likely that $\pi$ stacked pyrene aggregates deposit at the surface of the MWCNTs $\mid$ GDL for concentrations of $\mathrm{PyCO}_{2} \mathrm{H}$ in solution above $10 \mathrm{mM}$.

Catalyst integration and electrochemical characterization of the modified electrodes. The molecular catalyst was then immobilized on the $\mathrm{PyCO}_{2} \mathrm{H} \mid$ MWCNTs $\mid$ GDL. The modified electrodes were prepared by soaking the films with $8 \mu \mathrm{L}$ of NiArg at different concentrations for $5 \mathrm{~min}$, in a sealed vessel, before thorough rinsing to remove loosely bound catalysts. The electrodes prepared with various loadings of $\mathrm{PyCO}_{2} \mathrm{H}$ and NiArg were first characterized using cyclic voltammetry $(\mathrm{CV})$ in neutral $\mathrm{pH}$ conditions and under argon (Figure $3 \mathrm{~A}$ and $\mathrm{B}$ ). The negligible HER activity of the grafted catalyst at $\mathrm{pH} 7$ allowed to clearly observe the redox activity of the metal complex with negligible electrocatalytic contributions. The reversible redox signature of NiArg is observed at potentials ranging from $\mathrm{E}_{1 / 2}=-0.35$ to $-0.30 \mathrm{~V}$ vs SHE and was attributed to the $2 \mathrm{e}^{-} / 2 \mathrm{H}^{+}$redox process, centered at the metal. ${ }^{64,66}$ The $\mathrm{pH}$ dependency of the redox process was also studied and a $56 \mathrm{mV} / \mathrm{pH}$ unit drift was measured, confirming the proton coupled character of the electron transfer, as previously reported (Figure S2) ${ }^{64}$ At $\mathrm{pH} 7$, small variations of the $\mathrm{E}_{1 / 2}$ values seem to correlate both with the increase of $\mathrm{PyCO}_{2} \mathrm{H}$ and catalyst loading at the electrode surface, potentially due to local $\mathrm{pH}$ changes induced by the increasing surface concentration of carboxylate and guanidinium groups, responsible for an anodic and cathodic shift, respectively (Figure $\mathrm{S}_{3}$ and $\left.\mathrm{S}_{4} \mathrm{~A}\right)$. The measured peak-to-peak separation $\left(\Delta \mathrm{E}_{\mathrm{p}}\right)$ increased substantially from about $50 \mathrm{mV}$ at low catalyst loading to $120 \mathrm{mV}$ at higher loadings, while remaining constant upon variation of $\Gamma_{\mathrm{PyCO}_{2} \mathrm{H}}$, hinting a more sluggish electron transfer at higher catalyst loading (Figure $\left.\mathrm{S}_{4} \mathrm{~B}\right)$. In addition, the peak currents appeared to scale linearly with the scan rate, characteristic of an immobilized species, only at lower scan rates $\left(<75 \mathrm{mV} \mathrm{s}^{-1}\right)$ (Figure $\mathrm{S}_{5}$ and S6).
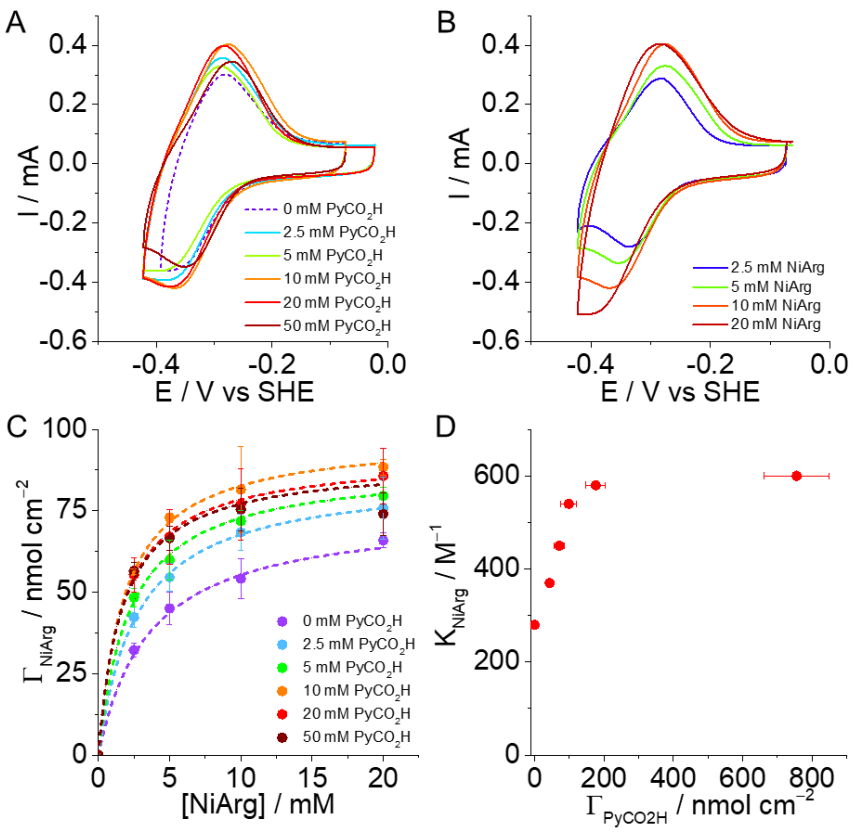

Figure 3: $\mathrm{CVs}$ of the NiArg $\left|\mathrm{PyCO}_{2} \mathrm{H}\right| \mathrm{MWCNTs} \mid \mathrm{GDL}$ electrodes prepared with: A) various concentrations of $\mathrm{PyCO}_{2} \mathrm{H}$ and $10 \mathrm{mM}$ of NiArg, and B) $5 \mathrm{mM}$ of $\mathrm{PyCO}_{2} \mathrm{H}$ and various concentrations of NiArg in potassium phosphate buffer 0.2 $\mathrm{M}, \mathrm{pH} 7,25^{\circ} \mathrm{C}$, under argon $\left(v=20 \mathrm{mV} \mathrm{s}^{-1}\right)$. CVs initial starting potential was the OCP and the initial scanning direction was cathodic; C) Evolution of the $\Gamma_{\mathrm{NiArg}}$ on $\mathrm{PyCO}_{2} \mathrm{H}|\mathrm{MWCNTs}|$ GDL (various concentrations of $\mathrm{PyCO}_{2} \mathrm{H}$ ) with the concentration of NiArg in the soaking solution; D) Evolution of the adsorption constant of NiArg as function of the carboxylate surface concentration.

This behavior, as well as the higher measured $\Delta \mathrm{E}$ peak values, can be explained by electrolyte mass transport limitations within the porous CNTs network as commonly observed in other nanoporous systems such as MOFsmodified electrodes. ${ }^{80,81}$ CVs experiments at increasing scan rates showed that the linear correlation of the peak currents with the scan rate decreased while the $\Delta \mathrm{E}_{\mathrm{p}}$ increased when the salinity was lowered (Figure $\mathrm{S}_{7}$ ) or when bulkier electrolytes were used (Figure S8), further attesting electrolyte mass transport limitation in the porous electrode.

As expected, the increase of concentration of NiArg in the soaking solution led to a rise in surface concentration of immobilized catalyst $\left(\Gamma_{\mathrm{NiArg}}\right)$ for all MWCNTs|GDL samples (Figure $3 \mathrm{~B}$ and $\mathrm{C}$ and $\mathrm{S} 9$ ). $\Gamma_{\mathrm{NiArg}}$ were calculated from the integration of the oxidation wave (at $20 \mathrm{mV} \mathrm{s}^{-1}$ ), accounting for 2 electrons transferred from NiArg. ${ }^{64,66} \Gamma_{\mathrm{NiArg}}$ increases with the soaking solution concentration of catalyst until reaching a maximum value of $88 \pm 3 \mathrm{nmol} \mathrm{cm}^{-2}$ for the $\mathrm{PyCO}_{2} \mathrm{H} \mid$ MWCNTs $\mid$ GDL electrodes incubated with $10 \mathrm{mM} \mathrm{PyCO}_{2} \mathrm{H}$ and in $20 \mathrm{mM}$ NiArg (Figure ${ }_{3} \mathrm{C}$ ). 
ICP-AES measurements from the digestions in $65 \%$ nitric acid of the MWCNT|GDL films confirmed the surface concentrations measured by redox wave integration with about $20 \%$ variation (Figure S10). The slightly higher loadings calculated with the ICP measurements can be explained by the presence of non-specifically bound and poorly electronically wired $\mathrm{Ni}$ complex within the porous MWCNTs|GDL. These numbers underline the great advantage of molecular structures, where a large majority of all grafted catalysts are electrochemically active.

Interestingly, $\Gamma_{\mathrm{NiArg}}$ value of $66 \pm 2 \mathrm{nmol} \mathrm{cm} \mathrm{cm}^{-2}$ could be reached with the unmodified MWCNTs|GDL hinting for a reasonably strong $\pi$-cation interaction between the charged complex and the $\pi$-conjugated MWCNT surface (Figure ${ }_{3} \mathrm{C}$ ). As described above for $\Gamma_{\mathrm{PyCO}_{2} \mathrm{H}}, \Gamma_{\mathrm{NiArg}}$ of the electroactive catalyst varies with the concentration of NiArg in the soaking solution and follows the same simple Langmuir binding isotherm (Figure ${ }_{3} \mathrm{C}$ ):

$$
\Gamma_{N i A r g}=\frac{\Gamma_{N i A r g \max } K_{\text {NiArg }}[N i A r g]}{1+K_{\text {NiArg }}[N i A r g]}
$$

where $\Gamma_{\text {NiArgmax }}$ is the maximum NiArg surface concentration for a monolayer of catalyst on the MWCNTs film $\left(\mathrm{nmol} \mathrm{cm}{ }^{-2}\right), \mathrm{K}_{\mathrm{NiArg}}$ is the adsorption equilibrium constant for NiArg $\left(\mathrm{M}^{-1}\right)$ and [NiArg] is the concentration of NiArg in the soaking solution (M). Along with the $33 \%$ increase in $\Gamma_{\text {NiArg }}$ obtained after modification of the MWCNTs surface, the $\mathrm{K}_{\mathrm{NiArg}}$ values for catalyst adsorption also rose more significantly from $280 \mathrm{M} \mathrm{M}^{-1}$ without $\mathrm{PyCO}_{2} \mathrm{H}$ to 600 $\mathrm{M}^{-1}$ with the highest surface concentration of carboxylic acid groups (50 mM) (Figure $3 \mathrm{D}$ and $\mathrm{Sil}$ ). This corresponds to binding energies of -14.0 and $-15.8 \mathrm{~kJ} \mathrm{~mol}^{-1}$ with MWCNTs $\mid$ GDL and $\mathrm{PyCO}_{2} \mathrm{H}|\mathrm{MWCNTs}| \mathrm{GDL}(50 \mathrm{mM}$ of $\mathrm{PyCO}_{2} \mathrm{H}$ ), respectively, in line with reported values for such cation- $\pi$ and electrostatic interactions (Figure S12). ${ }^{82}$ As electrochemical characterizations are performed out of the equilibrium (with no NiArg in solution), multiple redox cycling experiments were performed in order to probe the stability of the catalyst grafting at the electrode surface modified or not with the $\mathrm{PyCO}_{2} \mathrm{H}$ derivatives (Figure $\mathrm{S}_{13} \mathrm{~A}$ and $\mathrm{B}$ ). After more than ih of redox cycling and $100 \mathrm{CVs}$ scans, 75 and $65 \%$ of catalyst remained electroactive at the surface of the electrode modified with $10 \mathrm{mM}$ or no $\mathrm{PyCO}_{2} \mathrm{H}$, respectively (Figure $\mathrm{S}_{13} \mathrm{C}$ ). These numbers corroborate the $\mathrm{K}$ values described above and showcase a slow decrease of $\Gamma_{\mathrm{NiArg}}$ likely due to resolvation of the water soluble catalyst over time. These results further underline the benefit of introducing a carboxylate function $\mathrm{PyCO}_{2} \mathrm{H}$, through this mild non covalent modification strategy, both to maximize catalyst loading and improve the stability of the grafting.

Characterization and optimization of the HOR electrocatalytic performances. The catalytic activities towards HOR of all these different MWCNTs|GDL electrodes modified with NiArg were then evaluated in acidic electrolyte (0.5 $\mathrm{M} \mathrm{H}_{2} \mathrm{SO}_{4}$ ). Measurements under an $\mathrm{H}_{2}$ feed at the back of the working gas diffusion electrode were carried out in order to observe the maximum HOR activities. Importantly, an additional drying step following catalyst deposition was included in order to probe the impact of the hydration level of the catalytic layer on the HOR catalysis (Figure 4).

For all NiArg $\left|\mathrm{PyCO}_{2} \mathrm{H}\right|$ MWCNTs $\mid$ GDL electrodes prepared, CVs under argon feed show a reductive catalytic wave starting at o $\mathrm{V}$ vs RHE attributed to HER by NiArg (Figure $4 \mathrm{~A}$ ). Under $\mathrm{H}_{2}$, the large oxidation wave starting at o $\mathrm{V}$ vs RHE is attributed to the electrocatalytic HOR by NiArg, with no required overpotential, as previously reported (Figure $4 \mathrm{~B}$ )..$^{50,64,66}$ Using the modified electrode directly after rinsing (no drying step) allowed to maintain the layer fully hydrated resulting in low HOR current densities of $15 \pm 3 \mathrm{~mA} \mathrm{~cm}^{-2}$ at $0.4 \mathrm{~V}$ vs RHE, slightly higher than the HER contribution $\left(13 \pm 1 \mathrm{~mA} \mathrm{~cm}^{-2}\right.$ at $-0.2 \mathrm{~V}$ vs RHE). These currents are similar to previously reported values with NiArg immobilized on MWCNTs covalently modified with naphthoic acid residues. ${ }^{64}$ It has to be noted that the HER current only slightly drops from 15 to 13 $\mathrm{mA} \mathrm{cm}{ }^{-2}$ upon addition of $\mathrm{H}_{2}$ (Figure 4). This is in stark contrast with what can be observed in homogeneous conditions, where addition of $\mathrm{H}_{2}$ strongly impacts the HER contribution and where a noticeable bias for HOR can be observed (Figure S14). This behavior is well known for $\mathrm{H}_{2} \mathrm{ases}^{29,83}$ and has previously been observed for this catalyst in solution as well as on electrode. ${ }^{49,70}$ The difference between the data in solution and the data at the $\mathrm{PyCO}_{2} \mathrm{H}|\mathrm{MWCNTs}| \mathrm{GDL}$ surface suggests that the diffusion of $\mathrm{H}_{2}$ to the catalytic site is limiting in this fully hydrated layer configuration due to the low solubility of $\mathrm{H}_{2}$ in water.
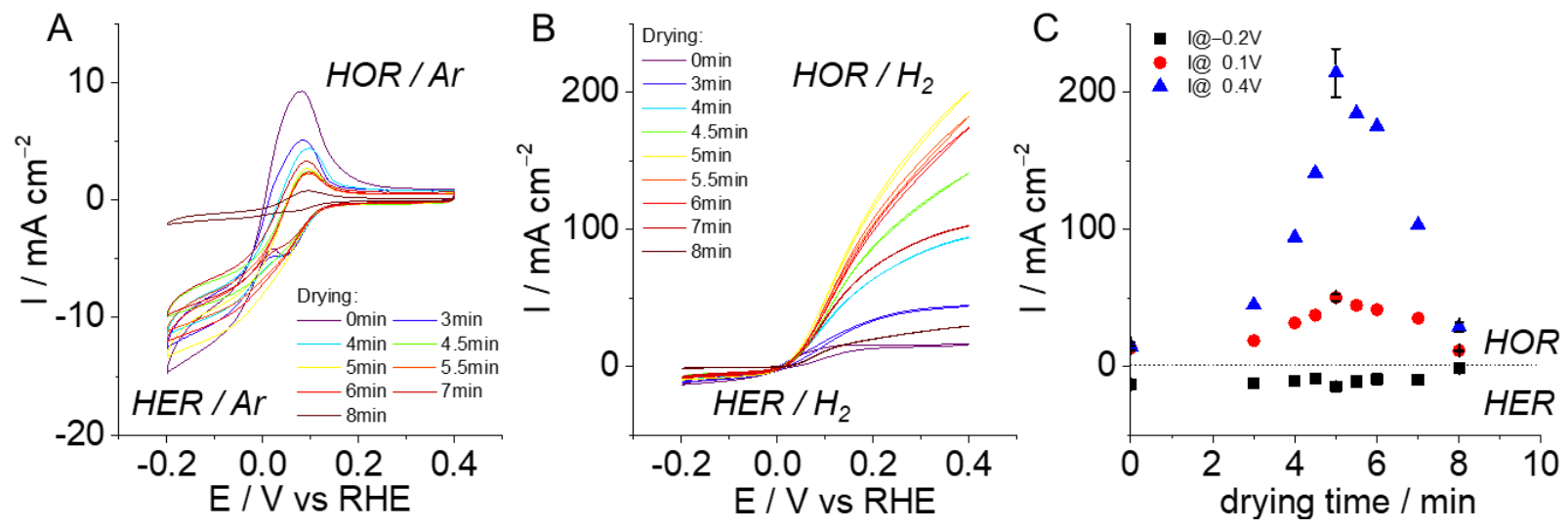
Figure 4: CVs of the NiArg $\left|\mathrm{PyCO}_{2} \mathrm{H}\right| \mathrm{MWCNTs} \mid$ GDL electrodes, modified with $10 \mathrm{mM} \mathrm{PyCO}_{2} \mathrm{H}$ and $10 \mathrm{mM}$ NiArg followed by a timed drying step of various duration with A) Argon and B) $\mathrm{H}_{2}$ as gas feed at the working electrode, respectively, in o.5 $\mathrm{M} \mathrm{H}_{2} \mathrm{SO}_{4}$ $\mathrm{pH} 0.3$ at $25^{\circ} \mathrm{C}\left(\mathrm{v}=20 \mathrm{mV} \mathrm{s}^{-1}\right)$. CVs initial starting potential was the OCP and the initial scanning direction was cathodic; $\left.\mathrm{C}\right)$ Evolution of the catalytic current values for HOR (at 0.1 and $0.4 \mathrm{~V}$ vs RHE, red dots and blue triangles, respectively) and for HER (at -0.2 V vs RHE, black squares) with the drying time of the electrode.

Increasing the duration of the drying step had a noticeable impact on both the HER and HOR currents (Figure $\left.{ }_{4} \mathrm{C}\right)$. Indeed, progressively extending this drying step led to higher HOR currents, up to a maximum of $54 \pm 3$ and $214 \pm 20 \mathrm{~mA} \mathrm{~cm}^{-2}$ at 0.1 and $0.4 \mathrm{~V}$ vs RHE, respectively, after 5 min drying (Figure $4 \mathrm{~B}$ and $\mathrm{C}$ ). Then, HOR activity slowly declined when the film was let to dry for longer. By contrast, the HER currents steadily decreased upon drying, falling from $-13 \pm 1 \mathrm{~mA} \mathrm{~cm}{ }^{-2}$ without drying step, to $1.5 \pm 0.5 \mathrm{~mA} \mathrm{~cm}^{-2}$ after $8 \mathrm{~min}$ of drying at $-0.2 \mathrm{~V}$ vs RHE (Figure $4 \mathrm{~A}$ and $\mathrm{C}$ ). This strong effect on both the HER and HOR performances upon drying of the active layer hints to a drastic change in active site availability to the electrolyte $\left(\mathrm{H}^{+}\right)$and the gaseous substrate $\left(\mathrm{H}_{2}\right)$.

In order to further support this hypothesis, CVs at increasing scan rates and for different drying times were performed on the $\mathrm{PyCO}_{2} \mathrm{H}|\mathrm{MWCNTs}| \mathrm{GDL}$ film. This allows to probe the variation of the electrochemically active surface area (ECSA) with the drying duration at $\mathrm{pH}$ 7 (Figure $\mathrm{S}_{15}$ and $\mathrm{S}_{16}$ ). When increasing the drying time, the capacitive current contribution is decreasing steadily, indicating a loss of the ECSA, from $54 \pm 2$ to $37 \pm 3 \mathrm{~cm}^{2}$ after $\mathrm{o}$ and 5 minutes, respectively (Figure S16C and D). For longer drying steps, a more significant drop in ECSA is measured until reaching only $9.6 \pm 0.4 \mathrm{~cm}^{2}$ after 8 minutes. Consequently to the loss of ECSA, the amount of electrochemically active catalytic sites dramatically decreases with longer drying steps, as observed from CVs performed at $\mathrm{pH} 7$ on the NiArg $\left|\mathrm{PyCO}_{2} \mathrm{H}\right| \mathrm{MWCNTs} \mid$ GDL electrode (Figure S17). Precisely, the apparent catalyst loading falls from $79 \pm 7 \mathrm{nmol} \mathrm{cm}{ }^{-2}$ without drying step to $7 \pm 2 \mathrm{nmol} \mathrm{cm}^{-2}$ after 8 minutes of drying.

These observations confirm an important change of ECSA and electroactive $\mathrm{Ni}$ sites availability upon modification of the hydration level of the catalytic layer (Figure 5). Without drying step, the aqueous electrolyte is expected to penetrate easily and fill the porous active layer. In these conditions, where most of the catalyst should be electrochemically active and $\mathrm{H}^{+}$can diffuse efficiently, a cata- lytic plateau is observed for HOR. This suggests substrate diffusion limitation which can be rationalized by the low solubility of $\mathrm{H}_{2}$ in aqueous electrolyte (Figure $5 \mathrm{~A}$ ). On the other hand, for longer drying steps, the layer is no longer hydrated. This likely facilitates $\mathrm{H}_{2}$ diffusion through the porous film but also prevents the electrolyte and $\mathrm{H}^{+}$to readily penetrate and diffuse within the now hydrophobic MWCNTs network. This results in smaller electrolyte/electrode interface with very few effectively connected active sites leading to both low HER and HOR catalytic currents (Figure ${ }_{5} \mathrm{C}$ ). The highest HOR performance is thus obtained at the best trade-off between electrolyte penetration through the film and $\mathrm{H}_{2}$ diffusion towards and from the catalytic site, potentially through hydrophobic channels in the porous MWCNTs network (Figure 5B).

The impact of the surface concentration of $\mathrm{PyCO}_{2} \mathrm{H}$ on HOR performances at optimized drying time was evaluated and maximum HOR current densities of $214 \pm 20 \mathrm{~mA}$ $\mathrm{cm}^{-2}$ at $0.4 \mathrm{~V}$ vs RHE were obtained with the NiArg $\left|\mathrm{PyCO}_{2} \mathrm{H}\right| \mathrm{MWCNTs} \mid \mathrm{GDL}$ electrodes (10 $\mathrm{mM} \mathrm{PyCO}_{2} \mathrm{H}$ ), dried for $5 \mathrm{~min}$ (Figure S18 and S19). Assuming that the amount of electrochemically active catalyst does not strongly vary between $\mathrm{pH} 7$ and 0.3 and that all the electrons collected come from HOR, experimental TOFs for HOR at $\mathrm{pH} 0.3$ and under $\mathrm{H}_{2}$ were calculated based on the catalyst loadings measured at $\mathrm{pH}$ 7. These varied only slightly between 10 and $17.5 \mathrm{~s}^{-1}\left(14 \mathrm{~s}^{-1}\right.$ for the best performing electrode) suggesting no obvious impact from the $\mathrm{PyCO}_{2} \mathrm{H}$ surface modification on the intrinsic HOR performances (Figure S18). Importantly, these most likely represent conservative TOF values as the apparent catalyst loadings measured at $\mathrm{pH} 7$ falls from $80 \pm 10 \mathrm{nmol}$ $\mathrm{cm}^{-2}$ to $32 \pm 4 \mathrm{nmol} \mathrm{cm}{ }^{-2}$ for the best performing anode, obtained with $10 \mathrm{mM} \mathrm{PyCO}_{2} \mathrm{H}$ and $10 \mathrm{mM}$ NiArg and after 5 min of drying (see above and Figure S17). Based on this updated catalyst loading, more accurate TOFs for HOR of about $37 \mathrm{~s}^{-1}$ can be estimated for the best performing anode. 

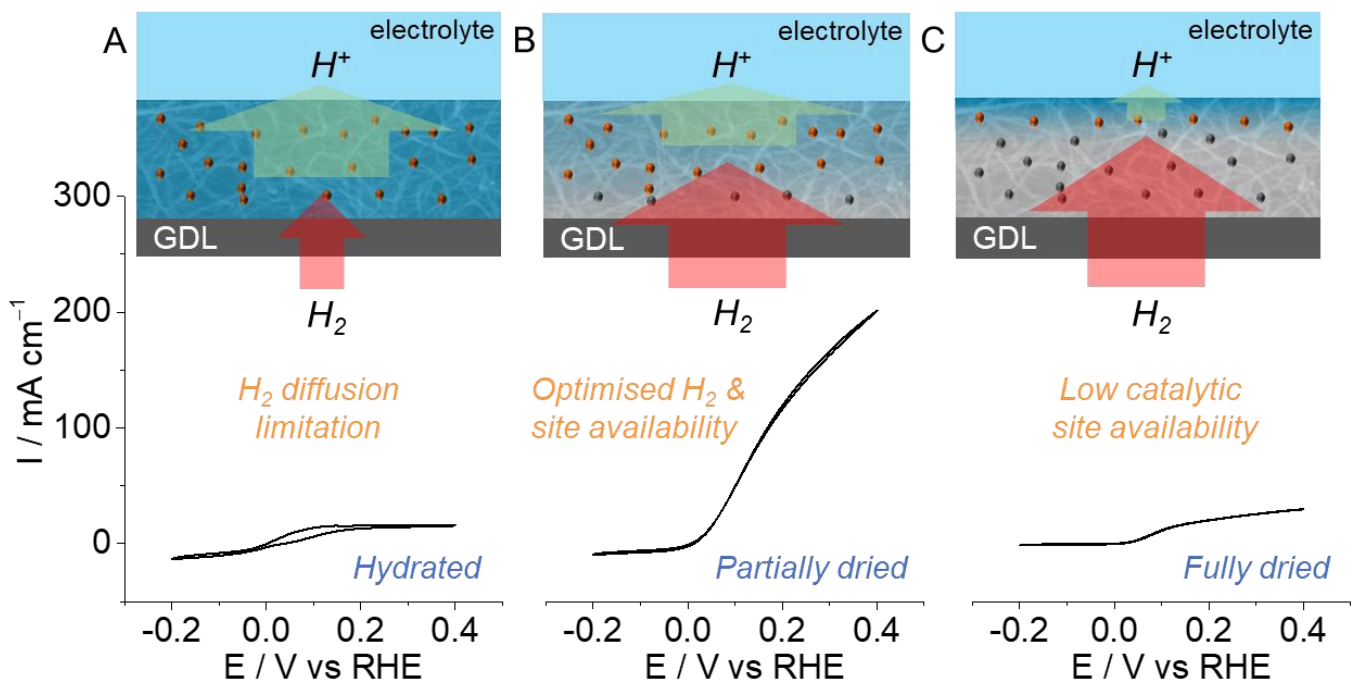

Figure 5: Schematic representations (up) and corresponding CV traces of the NiArg $\left|\mathrm{PyCO}_{2} \mathrm{H}\right| \mathrm{MWCNTs} \mid \mathrm{GDL}$ electrodes prepared with $10 \mathrm{mM} \mathrm{PyCO}{ }_{2} \mathrm{H}$ and $10 \mathrm{mM}$ NiArg, with the variation of drying time: A) o min, B) $5 \mathrm{~min}$ and C) 8 min in o.5 M $\mathrm{H}_{2} \mathrm{SO}_{4}, \mathrm{pH} 0.3$ at $25^{\circ} \mathrm{C}\left(\mathrm{v}=20 \mathrm{mV} \mathrm{s}^{-1}\right)$. Effectively wired NiArg sites are represented red spheres while the electrochemically inactive ones

in

grey.
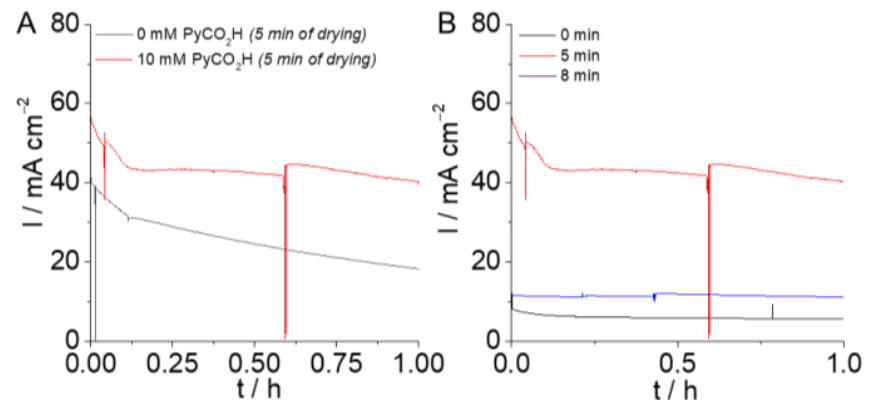

Figure 6: $\mathrm{CA}$ at $0.1 \mathrm{~V}$ vs $\operatorname{RHE}(\eta=0.1 \mathrm{~V})$ of $\mathrm{A})$ NiArg|MWCNTs |GDL (black curve) and NiArg $\left|\mathrm{PyCO}_{2} \mathrm{H}\right| \mathrm{MWCNTs} \mid$ GDL (red curve) electrodes with $10 \mathrm{mM}$ NiArg after $5 \mathrm{~min}$ of drying time; B) NiArg $\left|\mathrm{PyCO}_{2} \mathrm{H}\right| \mathrm{MWCNTs} \mid$ GDL electrode with $10 \mathrm{mM}$ NiArg after o min (black curve), 5 min (red curve) and 8 min (blue curve) of drying time under an $\mathrm{H}_{2}$ as gas feed at the working electrode in $0.5 \mathrm{M} \mathrm{H}_{2} \mathrm{SO}_{4}, \mathrm{pH} 0.3$ and at $25^{\circ} \mathrm{C}$. The drop in current observed at about $0.6 \mathrm{~h}$ is attributed to a gas bubble briefly blocking the surface of the electrode, causing the current to drop momentarily.

In order to study the influence of the $\mathrm{PyCO}_{2} \mathrm{H}$ anchor surface concentration on stability of the HOR catalysis over time, chronoamperometric measurements (CA) at 0.1 $\mathrm{V}$ vs RHE were carried out at $25^{\circ} \mathrm{C}$ with the NiArg $\left|\mathrm{PyCO}_{2} \mathrm{H}\right| \quad$ MWCNTs $\mid$ GDL and NiArg|MWCNTs $\mid$ GDL electrodes (Figure 6A). The overpotential $(\eta)$ of $0.1 \mathrm{~V}$ is specific to device operating conditions, in which more driving force is often required at the cathode for ORR.

With the NiArg|MWCNTs|GDL electrode, the initial catalytic currents of about $40 \mathrm{~mA} \mathrm{~cm}{ }^{-2}$ dropped continuously to $18 \mathrm{~mA} \mathrm{~cm}^{-2}$ within $\mathrm{ih}$, corresponding to only $45 \%$ of remaining catalytic HOR current. On the contrary, the NiArg $\left|\mathrm{PyCO}_{2} \mathrm{H}\right|$ MWCNTs $\mid$ GDL electrode showed higher initial currents of about $55 \mathrm{~mA} \mathrm{~cm}{ }^{-2}$ with a better stability as $75 \%$ of the overall current remained after $\mathrm{lh}$. For this electrode, most of the current decay was observed during the first 10 minutes of electrolysis after which the HOR current showed a good stability, retaining $93 \%$ over the next 50 minutes. Interestingly, the drying time also had an influence on the stability of the catalytic response. When the layer remained fully hydrated, only $60 \%$ of HOR activity remained after $1 \mathrm{~h}$ while when dried for longer, $96 \%$ of the initial activity could be retained (Figure 6B). CVs were recorded before and after CA measurements to compare the changes in electrocatalytic response after prolonged operation (Figure S2o). For both fully hydrated and partially dried layers the electrocatalytic responses decrease both in the HER and HOR regimes after electrolysis while remaining very stable with the electrode dried for longer. These results suggests that the initial lack of stability of the hydrated layers is not caused by the degradation of the catalytic center upon cycling, as the electrocatalytic response is stable in the case of the dried layer. The leaching out in the aqueous electrolyte of unspecifically bound NiArg sites in the first minutes of CA could explain such decay. In fact, ICP measurements performed on the film post-CA only allowed to observe $73 \%$ of the overall initial NiArg loading but corresponding to $90 \%$ of the electrochemically wired NiArg (Figure Sio). Alternatively, change in the electrode nanostructure within the hydrated layer over the course of the experiment could also explain this drop in activity, potentially following the drying of the layer under constant gas flow or the flooding of the film with the aqueous electrolyte.

The HOR activity of the NiArg $\left|\mathrm{PyCO}_{2} \mathrm{H}\right|$ MWCNTs $\mid$ GDL electrodes was finally studied at higher temperature in acidic electrolyte ( $0.5 \mathrm{M} \mathrm{H}_{2} \mathrm{SO}_{4}$ ) and with an $\mathrm{H}_{2}$ feed at the back of the working electrode to approach relevant operating temperatures for PEMFC (Figure 7). The meas- 
ured catalytic currents raised significantly with temperature, reaching record current densities for molecular HOR catalysis of $395 \pm 30 \mathrm{~mA} \mathrm{~cm}{ }^{-2}$ at $\eta=0.4 \mathrm{~V}$ and at $55^{\circ} \mathrm{C}$ (Figure ${ }_{7} \mathrm{~B}$ ). Considering a surface coverage of $\Gamma_{\text {NiArg }}=80$ $\pm 10 \mathrm{nmol} \mathrm{cm}{ }^{-2}$, experimental TOFs of $25 \mathrm{~s}^{-1}$ at $55^{\circ} \mathrm{C}$ for HOR can be calculated, a 2-fold increase over TOFs obtained at room temperature $\left(14 \mathrm{~s}^{-1}\right.$, Figure $\left.\mathrm{S} 18\right)$. This corresponds to a maximum TOF value of $64 \mathrm{~s}^{-1}$ when considering an apparent loading of $32 \pm 4 \mathrm{nmol} \mathrm{cm}^{-2}$ (see above). Moreover, high catalytic currents of $150 \pm 20 \mathrm{~mA} \mathrm{~cm}$ were obtained at $\eta=0.1 \mathrm{~V}$. This series of measurements allowed to estimate the corresponding activation energy to about $19 \mathrm{~kJ} \mathrm{~mol}^{-1}$, close to previously reported values for parent $\mathrm{Ni}$ complexes ${ }^{62,68}$ or Pt-based catalyst integrated in membrane electrode assemblies (Figure S21). ${ }^{73,84}$ This relatively low activation energy indicates that the observed catalytic response is probably not limited by the intrinsic turnover frequency of the catalyst but rather by substrate and product diffusion limitations within the film. ${ }^{68}$ The stability of the catalytic currents at $55^{\circ} \mathrm{C}$ could not be properly assessed due to fast gas bubbles formation at the surface of the electrode during measurement. Moreover, considering a maximum catalyst loading of $80 \mathrm{nmol} \mathrm{cm}$, mass activities of these anodes could be estimated at $14 \pm 2$ and $32 \pm 4 \mathrm{~A} \mathrm{mg}_{\mathrm{Ni}}{ }^{-1}$ at $25^{\circ} \mathrm{C}$ and $55^{\circ} \mathrm{C}$ respectively, and at $\eta=0.1 \mathrm{~V}$. At $\eta=0.4 \mathrm{~V}$, mass activities rise to $40 \pm 4$ and $83 \pm 6 \mathrm{~A} \mathrm{mg}_{\mathrm{Ni}}{ }^{-1}$ at $25^{\circ} \mathrm{C}$ and $55^{\circ} \mathrm{C}$, respectively (Figure 7 and $\mathrm{S}_{22}$ ). These mass activities now stand at less than 1 order of magnitude from the best mass activities obtained for ultra-low loading Pt-based anodes for HOR. $^{72,73}$

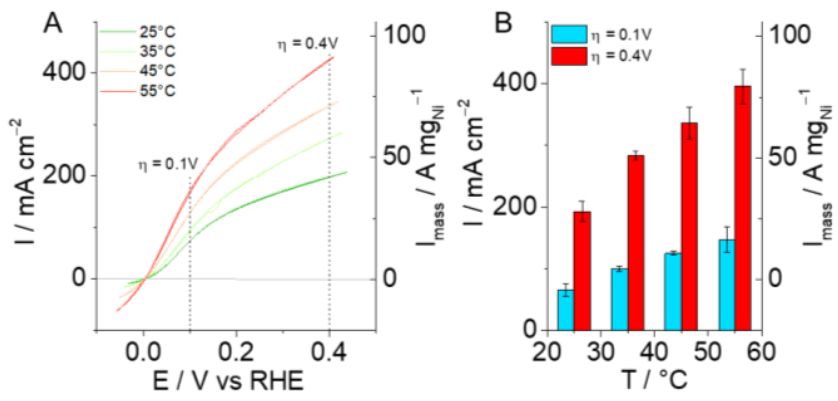

Figure 7: A) CVs traces and B) Average current densities taken from CVs at $0.1 \mathrm{~V}$ and $0.4 \mathrm{~V}$ vs RHE for the NiArg $\left|P_{2} \mathrm{CO}_{2} \mathrm{H}\right|$ MWCNTs $\mid$ GDL electrodes with $10 \mathrm{mM}$ $\mathrm{PyCO}_{2} \mathrm{H}$ and $10 \mathrm{mM}$ NiArg under an $\mathrm{H}_{2}$ gas feed at the working electrode in $0.5 \mathrm{M} \mathrm{H}_{2} \mathrm{SO}_{4}, \mathrm{pH} 0.3$ at $25 ; 35 ; 45$ and $55{ }^{\circ} \mathrm{C}(\mathrm{v}$ $\left.=20 \mathrm{mV} \mathrm{s}^{-1}\right)$. CVs initial starting potential was the OCP and the initial scanning direction was cathodic; Mass activities

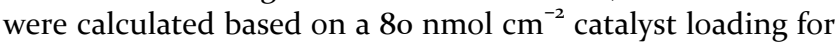
the best performing anodes.

\section{Conclusion}

This work describes an innovative non-covalent integration of a Ni-based molecular catalyst for HOR to MWCNTs films deposited onto GDL electrodes. This mild functionalization strategy allowed for a highly controlled and efficient catalyst loading at the surface of the MWCNTs, to reach high catalyst surface concentrations

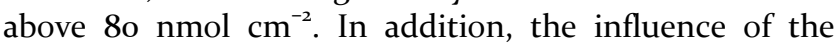

hydration level of the catalytic active layer on the electrocatalytic HOR performances of the electrodes was also studied. Control of the "wettability" of the layer allowed to reach new records for molecular HOR electrocatalysis. Industrially-relevant catalytic current densities as high as $210 \pm 20 \mathrm{~mA} \mathrm{~cm}^{-2}$ at $25^{\circ} \mathrm{C}$ and up to $390 \pm 30 \mathrm{~mA} \mathrm{~cm}{ }^{-2}$ at $55^{\circ} \mathrm{C}$ could be reached at $\eta=0.4 \mathrm{~V}$, with the best performing $\mathrm{NiArg}\left|\mathrm{PyCO}_{2} \mathrm{H}\right| \mathrm{MWCNTs} \mid \mathrm{GDL}$ anode (10 $\mathrm{mM} \mathrm{PyCO} \mathrm{P}_{2} \mathrm{H}, 10 \mathrm{mM}$ NiArg and 5 min drying).

These results are not only setting new benchmark for electrocatalytic molecular HOR, but also new standards in the field of molecular electrocatalysis, where only few studies have reported reaching such current densities, in the range of the $100 \mathrm{~mA} \mathrm{~cm}{ }^{-2}$. Following recent examples focused on molecular $\mathrm{CO}_{2}$ electroreduction, ${ }^{85,86}$ this work also highlights the great potential of molecular electrocatalysis to reach technologically relevant current densities for energy conversion, through appropriate electrode design and catalyst integration. The next step will involve tackling the stability issue of these modified electrodes, as well as their integration into membrane electrode assemblies and their subsequent operation in fully functional PGM-free PEMFCs. ${ }^{70}$

\section{ASSOCIATED CONTENT}

Supporting Information. Experimental details, materials, methods and additional supporting figures. The supplementary information is available free of charge via the Internet at http://pubs.acs.org.

\section{AUTHOR INFORMATION}

\section{Corresponding Authors}

* Dr. Vincent Artero; Vincent.artero@cea.fr ;

*Dr. Bertrand Reuillard; bertrand.reuillard@cea.fr

\section{Notes}

The authors declare no conflict of interests.

\section{ACKNOWLEDGMENT}

This work was supported by the French National Agency for Research (Labex ARCANE, CBH-EUR-GS, ANR-17-EUREooo3), the CEA PTC program on Materials and Processes. Fuel Cells and Hydrogen 2 Joint Undertaking (FCH-JU, GAN 779366). FCH-JU receives support from the European Union's Horizon 2020 research and innovation programme, Hydrogen Europe and Hydrogen Europe research.

\section{REFERENCES}

(1) Züttel, A.; Remhof, A.; Borgschulte, A.; Friedrichs, O. Hydrogen: The Future Energy Carrier. Philosophical Transactions of the Royal Society A: Mathematical, Physical and Engineering Sciences 2010, $368 \quad$ (1923), 3329-3342. https://doi.org/10.1098/rsta.2010.0113.

(2) Glenk, G.; Reichelstein, S. Economics of Converting Renewable Power to Hydrogen. Nature Energy 2019, 4 (3), 216222. https://doi.org/10.1038/s4156o-019-0326-1.

(3) Gordon, R. B.; Bertram, M.; Graedel, T. E. Metal Stocks and Sustainability. PNAS 2006, 103 (5), 1209-1214. https://doi.org/10.1073/pnas.0509498103. 
(4) Armaroli, N.; Balzani, V. The Hydrogen Issue. $\begin{array}{llll}\text { ChemSusChem 2011, } & 4 \quad \text { (1), }\end{array}$ https://doi.org/10.1002/cssc.201000182.

(5) Thompson, S. T.; Papageorgopoulos, D. Platinum Group Metal-Free Catalysts Boost Cost Competitiveness of Fuel Cell Vehicles. Nat Catal 2019, 2 (7), 558-561. https://doi.org/10.1038/s41929-019-0291-X.

(6) Jaouen, F.; Proietti, E.; Lefèvre, M.; Chenitz, R.; Dodelet, J.-P.; Wu, G.; Taek Chung, H.; Marie Johnston, C.; Zelenay, P. Recent Advances in Non-Precious Metal Catalysis for Oxygen - Reduction Reaction in Polymer Electrolyte Fuel Cells. Energy \& Environmental Science 2011, 4 (1), 114-130. https://doi.org/10.1039/CoEEooonF.

(7) Morozan, A.; Jousselme, B.; Palacin, S. Low- Platinum and Platinum -Free Catalysts for the Oxygen Reduction Reaction at Fuel Cell Cathodes. Energy $\mathcal{E}$ Environmental Science 2011, 4 (4), 1238-1254. https://doi.org/10.1039/CoEEoo6o1G.

(8) Gewirth, A. A.; Varnell, J. A.; DiAscro, A. M. Nonprecious Metal Catalysts for Oxygen Reduction in Heterogeneous Aqueous Systems. Chem. Rev. 2018, 118 (5), 2313-2339. https://doi.org/10.1021/acs.chemrev.7boo335.

(9) Wang, X. X.; Swihart, M. T.; Wu, G. Achievements, Challenges and Perspectives on Cathode Catalysts in Proton Exchange Membrane Fuel Cells for Transportation. Nature Catalysis 2019, 2 (7), 578-589. https://doi.org/10.1038/s41929-0190304-9.

(10) Morozan, A.; Jégou, P.; Jousselme, B.; Palacin, S. Electrochemical Performance of Annealed CobaltBenzotriazole/CNTs Catalysts towards the Oxygen Reduction Reaction. Phys. Chem. Chem. Phys. 2011, 13 (48), 21600-21607. https://doi.org/10.1039/C1CP23199E.

(11) Proietti, E.; Jaouen, F.; Lefèvre, M.; Larouche, N.; Tian, J.; Herranz, J.; Dodelet, J.-P. Iron-Based Cathode Catalyst with Enhanced Power Density in Polymer Electrolyte Membrane Fuel Cells. Nature Communications 2011, 2 (1), 416. https://doi.org/10.1038/ncomms1427.

(12) Zitolo, A.; Goellner, V.; Armel, V.; Sougrati, M.-T.; Mineva, T.; Stievano, L.; Fonda, E.; Jaouen, F. Identification of Catalytic Sites for Oxygen Reduction in Iron- and NitrogenDoped Graphene Materials. Nature Materials 2015, 14 (9), 937942. https://doi.org/10.1038/nmat4367.

(13) Jaouen, F.; Jones, D.; Coutard, N.; Artero, V.; Strasser, P.; Kucernak, A. R. Platinum Group Metal | Toward Catalysts Free of PGM Elements for PEMFC. Johnson Matthey Technol. Rev. 2018, $\quad 62 \quad$ (2), 231-255. https://doi.org/10.1595/205651318x696828.

(14) McIntyre, D. R.; Burstein, G. T.; Vossen, A. Effect of Carbon Monoxide on the Electrooxidation of Hydrogen by Tungsten Carbide. Journal of Power Sources 2002, 107 (1), 67-73. https://doi.org/10.1016/So378-7753(o1)oo987-9.

(15) Hara, Y.; Minami, N.; Itagaki, H. Synthesis and Characterization of High-Surface Area Tungsten Carbides and Application to Electrocatalytic Hydrogen Oxidation. Applied Catalysis A: General 2007, 323, 86-93. https://doi.org/10.1016/j.apcata.2007.02.o11.

(16) Nagai, M.; Yoshida, M.; Tominaga, H. Tungsten and Nickel Tungsten Carbides as Anode Electrocatalysts. Electrochimica Acta 2007, $52 \quad$ (17), 5430-5436. https://doi.org/10.1016/j.electacta.2007.02.065.

(17) Izhar, S.; Yoshida, M.; Nagai, M. Characterization and Performances of Cobalt-Tungsten and Molybdenum-Tungsten Carbides as Anode Catalyst for PEFC. Electrochimica Acta 2009, 54 (4), 1255-1262. https://doi.org/10.1016/j.electacta.2008.08.049.

(18) Zhuang, Z.; Giles, S. A.; Zheng, J.; Jenness, G. R.; Caratzoulas, S.; Vlachos, D. G.; Yan, Y. Nickel Supported on Nitrogen-Doped Carbon Nanotubes as Hydrogen Oxidation
Reaction Catalyst in Alkaline Electrolyte. Nat Commun 2016, 7 (1), 1-8. https://doi.org/10.1038/ncomms10141.

(19) Davydova, E. S.; Speck, F. D.; Paul, M. T. Y.; Dekel, D. R.; Cherevko, S. Stability Limits of Ni-Based Hydrogen Oxidation Electrocatalysts for Anion Exchange Membrane Fuel Cells. ACS Catal. 2019, 6837-6845. https://doi.org/10.1021/acscatal.9bo1582.

(20) Oshchepkov, A. G.; Braesch, G.; Bonnefont, A.; Savinova, E. R.; Chatenet, M. Recent Advances in the Understanding of Nickel-Based Catalysts for the Oxidation of Hydrogen-Containing Fuels in Alkaline Media. ACS Catal. 2020, 10 (13), 7043-7068. https://doi.org/10.1021/acscatal.ocoo101.

(21) Fontecilla-Camps, J. C.; Volbeda, A.; Cavazza, C.; Nicolet, Y. Structure/Function Relationships of [NiFe]- and [FeFe]Hydrogenases. Chem. Rev. 2007, 107 (10), 4273-4303. https://doi.org/10.1021/cro50195z.

(22) Vincent, K. A.; Parkin, A.; Armstrong, F. A. Investigating and Exploiting the Electrocatalytic Properties of Hydrogenases. Chem. Rev. 2007, 107 (10), 4366-4413. https://doi.org/10.1021/cro50191u.

(23) Lubitz, W.; Ogata, H.; Rüdiger, O.; Reijerse, E. Hydrogenases. Chem. Rev. 2014, 114 (8), 4081-4148. https://doi.org/10.1021/cr4005814.

(24) Léger, C.; Bertrand, P. Direct Electrochemistry of Redox Enzymes as a Tool for Mechanistic Studies. Chem. Rev. 2008, 108 (7), 2379-2438. https://doi.org/10.1021/cro680742.

(25) Milton, R. D.; Minteer, S. D. Direct Enzymatic Bioelectrocatalysis: Differentiating between Myth and Reality. Journal of The Royal Society Interface 2017, 14 (131), 20170253. https://doi.org/10.1098/rsif.2017.0253.

(26) Kornienko, N.; Ly, K. H.; Robinson, W. E.; Heidary, N.; Zhang, J. Z.; Reisner, E. Advancing Techniques for Investigating the Enzyme-Electrode Interface. Acc. Chem. Res. 2019, 52 (5), 1439-1448. https://doi.org/10.1021/acs.accounts.9booo87.

(27) Armstrong, F. A.; Belsey, N. A.; Cracknell, J. A.; Goldet, G.; Parkin, A.; Reisner, E.; Vincent, K. A.; Wait, A. F. Dynamic Electrochemical Investigations of Hydrogen Oxidation and Production by Enzymes and Implications for Future Technology. Chem. Soc. Rev. 2008, $38 \quad(1), \quad 36-51$. https://doi.org/10.1039/B801144N.

(28) Lojou, E. Hydrogenases as Catalysts for Fuel Cells: Strategies for Efficient Immobilization at Electrode Interfaces. Electrochimica Acta 2011, $56 \quad$ (28), $10385-10397$. https://doi.org/10.1016/j.electacta.2011.03.002.

(29) Sensi, M.; del Barrio, M.; Baffert, C.; Fourmond, V.; Léger, C. New Perspectives in Hydrogenase Direct Electrochemistry. Current Opinion in Electrochemistry 2017, 5 (1), 135-145. https://doi.org/10.1016/j.coelec.2017.08.005.

(30) Xu, L.; Armstrong, F. A. Optimizing the Power of Enzyme-Based Membrane-Less Hydrogen Fuel Cells for HydrogenRich H2-Air Mixtures. Energy Environ. Sci. 2013, 6 (7), 2166-2171. https://doi.org/10.1039/C3EE40791H.

(31) Lalaoui, N.; Poulpiquet, A. de; Haddad, R.; Goff, A. L.; Holzinger, M.; Gounel, S.; Mermoux, M.; Infossi, P.; Mano, N.; Lojou, E.; Cosnier, S. A Membraneless Air-Breathing Hydrogen Biofuel Cell Based on Direct Wiring of Thermostable Enzymes on Carbon Nanotube Electrodes. Chem. Commun. 2015, 51 (35), 7447-7450. https://doi.org/10.1039/C5CCo2166A.

(32) Szczesny, J.; Marković, N.; Conzuelo, F.; Zacarias, S.; Pereira, I. A. C.; Lubitz, W.; Plumeré, N.; Schuhmann, W.; Ruff, A. A Gas Breathing Hydrogen/Air Biofuel Cell Comprising a Redox Polymer/Hydrogenase-Based Bioanode. Nature Communications 2018, 9 (1), 4715. https://doi.org/10.1038/s41467-01807137-6.

(33) So, K.; Kitazumi, Y.; Shirai, O.; Nishikawa, K.; Higuchi, Y.; Kano, K. Direct Electron Transfer-Type Dual Gas Diffusion $\mathrm{H}_{2} / \mathrm{O}_{2}$ Biofuel Cells. J. Mater. Chem. A 2016, 4 (22), 8742-8749. https://doi.org/10.1039/C6TA02654K. 
(34) Mazurenko, I.; Monsalve, K.; Infossi, P.; GiudiciOrticoni, M.-T.; Topin, F.; Mano, N.; Lojou, E. Impact of Substrate Diffusion and Enzyme Distribution in ${ }_{3} \mathrm{D}$-Porous Electrodes: A Combined Electrochemical and Modelling Study of a Thermostable $\mathrm{H}_{2} / \mathrm{O}_{2}$ Enzymatic Fuel Cell. Energy Environ. Sci. 2017, 10 (9), 1966-1982. https://doi.org/10.1039/C7EEo183oD.

(35) Ciaccafava, A.; Infossi, P.; Ilbert, M.; Guiral, M.; Lecomte, S.; Giudici-Orticoni, M. T.; Lojou, E. Electrochemistry, AFM, and PM-IRRA Spectroscopy of Immobilized Hydrogenase: Role of a Hydrophobic Helix in Enzyme Orientation for Efficient $\mathrm{H} 2$ Oxidation. Angewandte Chemie 2012, 124 (4), 977-980. https://doi.org/10.1002/ange.201107053.

(36) Gentil, S.; Che Mansor, S. M.; Jamet, H.; Cosnier, S. Cavazza, C.; Le Goff, A. Oriented Immobilization of [NiFeSe] Hydrogenases on Covalently and Noncovalently Functionalized Carbon Nanotubes for Hz/Air Enzymatic Fuel Cells. ACS Catal. 2018, 8 (5), 3957-3964. https://doi.org/10.1021/acscatal.8boo7o8.

(37) Plumeré, N.; Rüdiger, O.; Oughli, A. A.; Williams, R.; Vivekananthan, J.; Pöller, S.; Schuhmann, W.; Lubitz, W. A Redox Hydrogel Protects Hydrogenase from High-Potential Deactivation and Oxygen Damage. Nature Chemistry 2014, 6 (9), 822-827. https://doi.org/10.1038/nchem.2022.

(38) Li, H.; Buesen, D.; Dementin, S.; Léger, C.; Fourmond, V.; Plumeré, N. Complete Protection of O2-Sensitive Catalysts in Thin Films. J. Am. Chem. Soc. 2019, 141 (42), 16734-16742. https://doi.org/10.1021/jacs.9bo679o.

(39) Li, H.; Münchberg, U.; Oughli, A. A.; Buesen, D.; Lubitz, W.; Freier, E.; Plumeré, N. Suppressing Hydrogen Peroxide Generation to Achieve Oxygen-Insensitivity of a [NiFe] Hydrogenase in Redox Active Films. Nature Communications 2020, 11 (1), 920. https://doi.org/10.1038/s41467-020-14673-7.

(40) Hardt, S.; Stapf, S.; Filmon, D. T.; Birrell, J. A.; Rüdiger, O.; Fourmond, V.; Léger, C.; Plumeré, N. Reversible H 2 Oxidation and Evolution by Hydrogenase Embedded in a Redox Polymer Film. Nature Catalysis 2021, 4 (3), 251-258. https://doi.org/10.1038/s41929-021-00586-1.

(41) Artero, V. Bioinspired Catalytic Materials for EnergyRelevant Conversions. Nature Energy 2017, 2, 17131. https://doi.org/10.1038/nenergy.2017.131.

(42) Trogadas, P.; Coppens, M.-O. Nature-Inspired Electrocatalysts and Devices for Energy Conversion. Chem. Soc. Rev. 2020, $\quad 49 \quad$ (10), 3107-3141. https://doi.org/10.1039/C8CSoo797G.

(43) Wilson, A. D.; Newell, R. H.; McNevin, M. J.; Muckerman, J. T.; Rakowski DuBois, M.; DuBois, D. L. Hydrogen Oxidation and Production Using Nickel-Based Molecular Catalysts with Positioned Proton Relays. J. Am. Chem. Soc. 20o6, 128 (1), 358-366. https://doi.org/10.1021/jao56442y.

(44) DuBois, D. L.; Bullock, R. M. Molecular Electrocatalysts for the Oxidation of Hydrogen and the Production of Hydrogen - The Role of Pendant Amines as Proton Relays. European Journal of Inorganic Chemistry 2011, 2011 (7), 1017-1027. https://doi.org/10.1002/ejic.201001081.

(45) Kleinhaus, J. T.; Wittkamp, F.; Yadav, S.; Siegmund, D.; Apfel, U.-P. [FeFe]-Hydrogenases: Maturation and Reactivity of Enzymatic Systems and Overview of Biomimetic Models. Chem. $\begin{array}{lllll}\text { Soc. Rev. 2021, } 50 \quad \text { (3), 1668-1784. } & \end{array}$ https://doi.org/10.1039/DoCSo1089H.

(46) Jain, A.; Reback, M. L.; Lindstrom, M. L.; Thogerson, C. E.; Helm, M. L.; Appel, A. M.; Shaw, W. J. Investigating the Role of the Outer-Coordination Sphere in $\left[\mathrm{Ni}\left(\mathrm{PPh}_{2} \mathrm{NPh}_{2} \mathrm{R}_{2}\right)_{2}\right]_{2}+$ Hydrogenase Mimics. Inorg. Chem. 2012, 51 (12), 6592-6602. https://doi.org/10.1021/ic300149x.

(47) Dutta, A.; Lense, S.; Hou, J.; Engelhard, M. H.; Roberts, J. A. S.; Shaw, W. J. Minimal Proton Channel Enables H2 Oxidation and Production with a Water-Soluble Nickel-Based Catalyst.
J. Am. Chem. Soc. 2013, 135 (49), 18490-18496. https://doi.org/10.1021/ja407826d.

(48) Ginovska-Pangovska, B.; Dutta, A.; Reback, M. L.; Linehan, J. C.; Shaw, W. J. Beyond the Active Site: The Impact of the Outer Coordination Sphere on Electrocatalysts for Hydrogen Production and Oxidation. Acc. Chem. Res. 2014, 47 (8), 26212630. https://doi.org/10.1021/ar5001742.

(49) Dutta, A.; DuBois, D. L.; Roberts, J. A. S.; Shaw, W. J. Amino Acid Modified Ni Catalyst Exhibits Reversible Hz Oxidation/Production over a Broad PH Range at Elevated Temperatures. PNAS 2014, 111 (46), 16286-16291. https://doi.org/10.1073/pnas.1416381111.

(50) Dutta, A.; Roberts, J. A. S.; Shaw, W. J. ArginineContaining Ligands Enhance $\mathrm{H}_{2}$ Oxidation Catalyst Performance. Angew. Chem. Int. Ed. 2014, 53 (25), 6487-6491. https://doi.org/10.1002/anie.201402304.

(51) Dutta, A.; Ginovska, B.; Raugei, S.; Roberts, J. A. S.; Shaw, W. J. Optimizing Conditions for Utilization of an $\mathrm{H}_{2}$ Oxidation Catalyst with Outer Coordination Sphere Functionalities. Dalton Trans. 2016, $45 \quad$ (24), 9786-9793. https://doi.org/10.1039/C6DToo28oC.

(52) Coutard, N.; Kaeffer, N.; Artero, V. Molecular Engineered Nanomaterials for Catalytic Hydrogen Evolution and Oxidation. Chem. Commun. 2016, 52 (95), 13728-13748. https://doi.org/10.1039/C6CCo6311J.

(53) Bullock, R. M.; Das, A. K.; Appel, A. M. Surface Immobilization of Molecular Electrocatalysts for Energy Conversion. Chem. Eur. J. 2017, 23 (32), 7626-7641. https://doi.org/10.1002/chem.201605066.

(54) Dalle, K. E.; Warnan, J.; Leung, J. J.; Reuillard, B.; Karmel, I. S.; Reisner, E. Electro- and Solar-Driven Fuel Synthesis with First Row Transition Metal Complexes. Chem. Rev. 2019, 119 (4), 2752-2875. https://doi.org/10.1021/acs.chemrev.8boo392.

(55) Goff, A. L.; Artero, V.; Jousselme, B.; Tran, P. D.; Guillet, N.; Métayé, R.; Fihri, A.; Palacin, S.; Fontecave, M. From Hydrogenases to Noble Metal-Free Catalytic Nanomaterials for H2 Production and Uptake. Science 2009, 326 (5958), 1384-1387. https://doi.org/10.1126/science.1179773.

(56) Tran, P. D.; Le Goff, A.; Heidkamp, J.; Jousselme, B.; Guillet, N.; Palacin, S.; Dau, H.; Fontecave, M.; Artero, V. Noncovalent Modification of Carbon Nanotubes with PyreneFunctionalized Nickel Complexes: Carbon Monoxide Tolerant Catalysts for Hydrogen Evolution and Uptake. Angewandte Chemie International Edition 2011, 50 (6), 1371-1374. https://doi.org/10.1002/anie.201005427.

(57) Moore, G. F.; Sharp, I. D. A Noble-Metal-Free Hydrogen Evolution Catalyst Grafted to Visible Light-Absorbing Semiconductors. J. Phys. Chem. Lett. 2013, 4 (4), 568-572. https://doi.org/10.1021/jz400028z.

(58) Das, A. K.; Engelhard, M. H.; Bullock, R. M.; Roberts, J. A. S. A Hydrogen-Evolving $\mathrm{Ni}\left(\mathrm{P}_{2} \mathrm{~N}_{2}\right)_{2}$ Electrocatalyst Covalently Attached to a Glassy Carbon Electrode: Preparation, Characterization, and Catalysis. Comparisons with the Homogeneous Analogue. Inorg. Chem. 2014, 53 (13), 6875-6885. https://doi.org/10.1021/ic500701a.

(59) Seo, J.; Pekarek, R. T.; Rose, M. J. Photoelectrochemical Operation of a Surface-Bound, Nickel-Phosphine $\mathrm{H}_{2}$ Evolution Catalyst on p-Si(111): A Molecular Semiconductor|catalyst Construct. Chem. Commun. 2015, 51 (68), $13264-13267$. https://doi.org/10.1039/C5CCo28o2G.

(6o) Kim, H. J.; Seo, J.; Rose, M. J. H2 Photogeneration Using a Phosphonate-Anchored Ni-PNP Catalyst on a Band-EdgeModified p-Si(111)|AZO Construct. ACS Appl. Mater. Interfaces 2016, 8 (2), 1061-1066. https://doi.org/10.1021/acsami.5bo9902.

(61) Rodriguez-Maciá, P.; Dutta, A.; Lubitz, W.; Shaw, W. J.; Rüdiger, O. Direct Comparison of the Performance of a BioInspired Synthetic Nickel Catalyst and a [NiFe]-Hydrogenase, 
Both Covalently Attached to Electrodes. Angewandte Chemie International Edition 2015, 54 (42), 12303-12307. https://doi.org/10.1002/anie.201502364.

(62) N. Huan, T.; T. Jane, R.; Benayad, A.; Guetaz, L.; D. Tran, P.; Artero, V. Bio-Inspired Noble Metal-Free Nanomaterials Approaching Platinum Performances for $\mathrm{H}_{2}$ Evolution and Uptake. Energy E Environmental Science 2016, 9 (3), 940-947. https://doi.org/10.1039/C5EE02739J.

(63) Rosser, T. E.; Gross, M. A.; Lai, Y.-H.; Reisner, E. Precious-Metal Free Photoelectrochemical Water Splitting with Immobilised Molecular Ni and Fe Redox Catalysts. Chem. Sci. 2016, 7 (7), 4024-4035. https://doi.org/10.1039/C5SCo4863J.

(64) Gentil, S.; Lalaoui, N.; Dutta, A.; Nedellec, Y.; Cosnier, S.; Shaw, W. J.; Artero, V.; Le Goff, A. Carbon-NanotubeSupported Bio-Inspired Nickel Catalyst and Its Integration in Hybrid Hydrogen/Air Fuel Cells. Angew. Chem. Int. Ed. 2017, 56 (7), 1845-1849. https://doi.org/10.1002/anie.201611532.

(65) Creissen, C. E.; Warnan, J.; Antón-García, D.; Farré, Y.; Odobel, F.; Reisner, E. Inverse Opal $\mathrm{CuCrO}_{2}$ Photocathodes for $\mathrm{H}_{2}$ Production Using Organic Dyes and a Molecular Ni Catalyst. ACS Catal. 2019, 9 (10), 9530-9538. https://doi.org/10.1021/acscatal.9bo2984.

(66) Reuillard, B.; Blanco, M.; Calvillo, L.; Coutard, N.; Ghedjatti, A.; Chenevier, P.; Agnoli, S.; Otyepka, M.; Granozzi, G.; Artero, V. Noncovalent Integration of a Bioinspired Ni Catalyst to Graphene Acid for Reversible Electrocatalytic Hydrogen Oxidation. ACS Appl. Mater. Interfaces 2020, 12 (5), 5805-5811. https://doi.org/10.1021/acsami.9b18922.

(67) Gurrentz, J. M.; Rose, M. J. Non-Catalytic Benefits of $\mathrm{Ni}$ (II) Binding to an Si(111)-PNP Construct for Photoelectrochemical Hydrogen Evolution Reaction: Metal Ion Induced Flat Band Potential Modulation. J. Am. Chem. Soc. 2020, 142 (12), 5657-5667. https://doi.org/10.1021/jacs.9b12824.

(68) Tran, P. D.; Morozan, A.; Archambault, S.; Heidkamp, J.; Chenevier, P.; Dau, H.; Fontecave, M.; Martinent, A.; Jousselme, B.; Artero, V. A Noble Metal-Free Proton-Exchange Membrane Fuel Cell Based on Bio-Inspired Molecular Catalysts. Chem. Sci. 2015, 6 (3), 2050-2053. https://doi.org/10.1039/C4SC03774J.

(69) Gentil, S.; Molloy, J. K.; Carrière, M.; Hobballah, A.; Dutta, A.; Cosnier, S.; Shaw, W. J.; Gellon, G.; Belle, C.; Artero, V.; Thomas, F.; Le Goff, A. A Nanotube-Supported Dicopper Complex Enhances Pt-Free Molecular H2/Air Fuel Cells. Joule 2019, 3 (8), 2020-2029. https://doi.org/10.1016/j.joule.2019.07.001.

(70) Coutard, N.; Reuillard, B.; Huan, T. N.; Valentino, F.; Jane, R. T.; Gentil, S.; Andreiadis, E. S.; Le Goff, A.; Asset, T.; Maillard, F.; Jousselme, B.; Morozan, A.; Lyonnard, S.; Artero, V.; Chenevier, P. Impact of Ionomer Structuration on the Performance of Bio-Inspired Noble-Metal-Free Fuel Cell Anodes. Chem $\begin{array}{lllll}\text { Catalysis } & \text { 2021, } & 1 & \text { (1), } & \text { 88-105. }\end{array}$ https://doi.org/10.1016/j.checat.2021.01.o01.

(71) Hydrogen and Fuel Cell Technologies Office. Hydrogen and Fuel Cell Technologies Office Multi-Year Research, Development, and Demonstration Plan; Department of Energy, 2014.

(72) Zalitis, C. M.; Kramer, D.; Kucernak, A. R. Electrocatalytic Performance of Fuel Cell Reactions at Low Catalyst Loading and High Mass Transport. Phys. Chem. Chem. Phys.

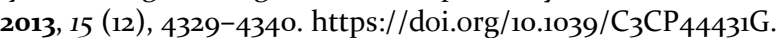

(73) Zalitis, C. M.; Sharman, J.; Wright, E.; Kucernak, A. R. Properties of the Hydrogen Oxidation Reaction on Pt/C Catalysts at Optimised High Mass Transport Conditions and Its Relevance to the Anode Reaction in PEFCs and Cathode Reactions in Electrolysers. Electrochimica Acta 2015, 176, 763-776. https://doi.org/10.1016/j.electacta.2015.06.146.

(74) Orfanidi, A.; Madkikar, P.; El-Sayed, H. A.; Harzer, G. S.; Kratky, T.; Gasteiger, H. A. The Key to High Performance Low
Pt Loaded Electrodes. J. Electrochem. Soc. 2017, 164 (4), F418. https://doi.org/10.1149/2.1621704jes.

(75) Li, F.; Zhang, B.; Li, X.; Jiang, Y.; Chen, L.; Li, Y.; Sun, L. Highly Efficient Oxidation of Water by a Molecular Catalyst Immobilized on Carbon Nanotubes. Angew. Chem. Int. Ed. 2011, 50 (51), 12276-12279. https://doi.org/10.1002/anie.201105044.

(76) Blakemore, J. D.; Gupta, A.; Warren, J. J.; Brunschwig, B. S.; Gray, H. B. Noncovalent Immobilization of Electrocatalysts on Carbon Electrodes for Fuel Production. J. Am. Chem. Soc. 2013, 135 (49), 18288-18291. https://doi.org/10.1021/ja4099609.

(77) Reuillard, B.; Warnan, J.; Leung, J. J.; Wakerley, D. W.; Reisner, E. A Poly(Cobaloxime)/Carbon Nanotube Electrode: Freestanding Buckypaper with Polymer-Enhanced H2-Evolution Performance. Angew. Chem. Int. Ed. 2016, 55 (12), 3952-3957. https://doi.org/10.1002/anie.201511378.

(78) Reuillard, B.; Ly, K. H.; Rosser, T. E.; Kuehnel, M. F.; Zebger, I.; Reisner, E. Tuning Product Selectivity for Aqueous $\mathrm{CO}_{2}$ Reduction with a Mn(Bipyridine)-Pyrene Catalyst Immobilized on a Carbon Nanotube Electrode. J. Am. Chem. Soc. 2017, 139 (41), 14425-14435. https://doi.org/10.1021/jacs.7bo6269.

(79) Reuillard, B.; Goff, A. L.; Cosnier, S. Non-Covalent Double Functionalization of Carbon Nanotubes with a NADH Oxidation Ru(II)-Based Molecular Catalyst and a NADDependent Glucose Dehydrogenase. Chem. Commun. 2014, 50 (79), 11731-11734. https://doi.org/10.1039/C4CCo4758C.

(8o) Roy, S.; Huang, Z.; Bhunia, A.; Castner, A.; Gupta, A. K.; Zou, X.; Ott, S. Electrocatalytic Hydrogen Evolution from a Cobaloxime-Based Metal-Organic Framework Thin Film. J. Am. Chem. Soc. 2019, $141 \quad$ (40), 15942-15950. https://doi.org/10.1021/jacs.9bo7084.

(81) Johnson, B. A.; Beiler, A. M.; McCarthy, B. D.; Ott, S. Transport Phenomena: Challenges and Opportunities for Molecular Catalysis in Metal-Organic Frameworks. J. Am. Chem. $\begin{array}{llll}\text { Soc. } & 2020, & 142 & \text { (28), }\end{array}$ https://doi.org/10.1021/jacs.oc02899.

(82) Schneider, H.-J. Binding Mechanisms in Supramolecular Complexes. Angewandte Chemie International Edition 2009, $48 \quad$ (22), $3924-3977$. https://doi.org/10.1002/anie.200802947.

(83) Fourmond, V.; Baffert, C.; Sybirna, K.; Dementin, S.; Abou-Hamdan, A.; Meynial-Salles, I.; Soucaille, P.; Bottin, H.; Léger, $\mathrm{C}$. The Mechanism of Inhibition by $\mathrm{H}_{2}$ of $\mathrm{H}_{2}$-Evolution by Hydrogenases. Chem. Commun. 2013, 49 (61), 6840-6842.

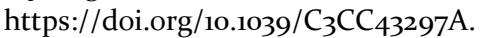

(84) Durst, J.; Simon, C.; Hasché, F.; Gasteiger, H. A. Hydrogen Oxidation and Evolution Reaction Kinetics on Carbon Supported Pt, Ir, Rh, and Pd Electrocatalysts in Acidic Media. J. $\begin{array}{llllll}\text { Electrochem. } & \text { Soc. } & \text { 2014, } & 162 & \text { (1), } & \text { Figo. }\end{array}$ https://doi.org/10.1149/2.09815oijes.

(85) Wang, M.; Torbensen, K.; Salvatore, D.; Ren, S.; Joulié, D.; Dumoulin, F.; Mendoza, D.; Lassalle-Kaiser, B.; Ișci, U.; Berlinguette, C. P.; Robert, M. CO 2 Electrochemical Catalytic Reduction with a Highly Active Cobalt Phthalocyanine. Nature $\begin{array}{lllll}\text { Communications } & \text { 2019, } & 10 & \text { (1), } & 3602 .\end{array}$ https://doi.org/10.1038/s41467-019-11542-w.

(86) Zhang, X.; Wang, Y.; Gu, M.; Wang, M.; Zhang, Z.; Pan, W.; Jiang, Z.; Zheng, H.; Lucero, M.; Wang, H.; Sterbinsky, G. E.; Ma, Q.; Wang, Y.-G.; Feng, Z.; Li, J.; Dai, H.; Liang, Y. Molecular Engineering of Dispersed Nickel Phthalocyanines on Carbon Nanotubes for Selective CO 2 Reduction. Nature Energy 2020, 5 (9), 684-692. https://doi.org/10.1038/s41560-020-0667-9. 


\section{ToC}

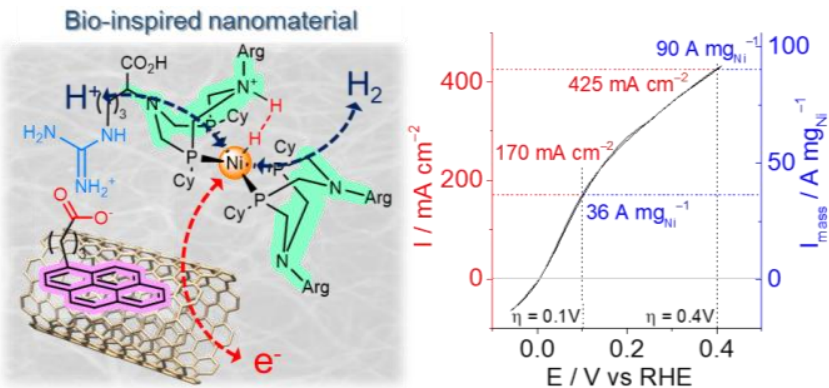

